\title{
Scanning Electron Microscopy of Icerya aegyptiaca (Douglas, 1890) (Hemiptera: Monophlebidae)
}

\author{
Sahar M. Beshr ${ }^{1}$
}

\begin{abstract}
The present study deals with the morphological study with both Light and Electron microscope of Icerya aegyptiaca (Douglas, 1890). It is revealed that the body regions are indistinct with convexed dorsum and flattened venter. Body covered with tufts of white waxy secretions and surrounded with submarginal long processes which covers the ovisac. The external features of the adult female such as, antennae, eyes, legs and thoracic and abdominal spiracles with their measurements were described in details. The Ultrastructure of derm pores with their variations in size, type and distribution were also explained with measurements. Only one circatrix is recorded in this mealy bug.
\end{abstract}

Keywords: Ultrastructure- morphology, Icerya aegypyiaca, mealy bugs.

\section{INTRODUCTION}

Scale insects are important economically because they have long been known as one of the most destructive pests of agriculture, horticulture and forestry in several countries. (Williams \& Watson, 1990; Miller \& Davidson, 1990; Miller et al., 2005).

Scale insects are divided into either 22 (Ben- Dov et al., 2006) or about 30 extant families (Koteja, 1996, 2001; Miller et al., 2007).

Scale insects and Mealy bugs comprise the super family Coccoidea in the Order Homoptera are divided traditionally into two informal groups, the primitive archaeococcoids in which adult female possess abdominal spiracles (Orthozoidea) and the advanced neococcoids in which the adult female do not have abdominal spiracles (Borchsenias, 1956; Koteja, 1974).

The primitive scale insects were classified by Morrison, (1928) into two families i.e. Ortheziidae and Margarodidae. In Egypt, the family Margarodidae is represented by six species (Ezzat and Nada, 1986). Three of them are belonging to the genus Icerya Signoret, 1875; Icerya aegyptiaca (Douglas, 1890), Icerya purchasi Maskell, 1878, and Icerya seychellarum (Westwood, 1855), that were originally described by Morrison, (1928).

Gullan and Cook (2007) reported that the neococcoids form a monophyletic group supported by both morphological and genetic data. In contrast the monophyly of the archaeococcoids is uncertain and the higher level ranks within it have been controversial.

Recent phylogenetic studies using molecular and morphological data conducted by Gullan and Cock (2007) supported the recognition of up to 15 extant families of archaeococcoids, including 11 families for the former Margarodidae. They also stated that relationships among most scale insect families are unresolved in phylogenetic trees based on nuclear DNA sequences, and most nodes in trees based on morphological characters. Later on, Unruh and Gullan (2008 a) published a molecular phylogeny of scale insects tribe Iceryini, they proved that four of the five genera belonging to this tribe are not monophyletic. In another investigation(2008 b), they considered genus Icerya as a member of family Monophlebidae instead of Margarodidae and revealed that their hypothesis of relationships was supported by morphological characters of the adult females, especially features of the wax-extruding cuticular pores.

Aim of the present work is to study the ultrastructure of the external characteristic features of Icerya aegyptiaca (Douglas, 1890).

\section{MATERIALS AND METHODS}

Identification of Mealy bugs in practically all cases is based upon the adult female, (Carnes, 1907). Morrison's traditional classification (1928) was also based largely on the morphology of adult females, so the present study depends on adult females.

\section{1-Preparing of the specimens for the Scanning} Electron Microscopy (SEM):

Adult females of Icerya egyptiaca (Douglas, 1890) were collected from leaves of croton, Codiaeum variegatum, in Alexandria.

The covering wax of the specimen was dissolved by using tetrahydrochlorofurane and chloroform $3: 1$. They were fixed in $2.5 \%$ glutaraldehyde. Then rinsed in phosphate buffer $(\mathrm{PH}=7.4)$ at room temperature, and post fixed with $2 \% \mathrm{O} 2 \mathrm{SO} 4(1.5 \mathrm{~h})$. After dehydration in a graded series of alcohols (50, 70, 90, 95 and 100\% each for $15 \mathrm{~min}$.) and than specimens were transfered to acetone $15 \mathrm{~min}$. Specimens were then prepared for the Scanning Electron Microscope (dried at the critical point PELCOCPD2, mounted on a stub by means of a double sided sticky transparent tape, and coated with

\footnotetext{
${ }^{1}$ Plant Protection Institute; A.R.C. Sabahia, Alexandria, Egypt. Received November5, 2015, Accepted December13, 2015
} 
gold in the PELCO SC-6-duster. They were examined with Jeol GSM 5300, Scanning Electron Microscope in the Faculty of Science, Alexandria University.

\section{2-Preparing the Specimens for Light microscoping examination:}

Wax secretions of the specimens dissolved in xylene, the body of the insect carefully punctured with a fine pin or a needle. Then heated in $\mathrm{NaOH} 10 \%$ using water bath to about $80^{\circ} \mathrm{C}$ for approximately one hour. The specimens were then washed several times in water, then transfered to a series of alcohol $(35,50,70 \%)$ for $15 \mathrm{~min}$. each. Specimens were mounted in hoyer's solution and dried in oven at $50^{\circ} \mathrm{C}$ for two weeks.

\section{RESULTS}

\section{General appearance:}

\section{Unmounted material:}

The adut female of Icerya aegytiaca (Douglas, 1890 ) is covered with lumps of white waxy secretions, about 20 waxy processes are surrounded the body margin, six short and stout processes on the anterior part of the body directed back wards followed by $12-14$ long slender tapered posterior extensions on the posterior body margin. These extensions which develops from the ventral surface of the abdomen giving it a fluted appearance.

\section{Side mounted material:}

Adult female oval to pyriform in shape, $5 \mathrm{~mm}$ long, yellowish orange in colour; legs, antennae and eyes dark brown.

\section{Microscopical features:}

The main body region often are indistinct and fused (Fig -1 ), the dorsal side is usually convex with the ventral side flat. Antennae are eleven segmented, the last of which being by far the longest, while the segments from the sixth to the tenth are equal. The scape broad at base, becoming narrow distally (Fig-2) Lengths of the antennal segments 1 to 11 , are measured in microns as followes $(100,70,90,40,40$, from sixth to tenth 50,120$)$ respectively. Eyes are simple and conical in shape, about 60 in diameter (Fig. $2 \& 3$ ). The mouth parts like all the superfamily Coccoidea consists of looped retracted stylets received into a long internal pouch (crumina) extending backwards from above the base of the labium into the thorax till the base of the abdomen (Fig. 4). The beak (labium) conical in shape, it is three segmented with setae measuring 220

$\mu$ at base, the two basal segments are very narrow (Fig.1, $4 \&$ 5). Adult and nymphs are able to protrude their thread like mouth stylets from the head to insert them into plant tissue (Snodgrass, 1935). There are three pairs of well developed thoracic legs (Fig. $6 \&$ 7), coxa bears raw of 4 special seta on its lower edge, the fumer is comparatively swollen and stout $\left(500 \mu^{\mu}\right)$ in length. The tibia is slightly longer than fumer ( $550{ }^{t h}$ ), while the tarsus is less than the half length of the tibia (200 $\mu$ ), claw strong and curved (50 $\mu$ ), tarsal and claw digitules not knobbed (Fig. 7)

There are two pairs of large heavily chitnized thoracic spiracles (Fig. $6 \&$ 8) the small anterior one measured $90 \mu$ in length and $50 \mu$ in width while the large posterior one measured $140 \mu$ long axis and 100 $\mu$ short axis. The abdominal piracles much smaller than the thoracia ones (Fig. 9), they are three pairs lies ventrally at the end of the abdomen. They are relatively simple, consisting a bell - shaped atrium (Fig- 10) and a short narrow tube, the circular opening of which

measured about $17.5 \mu$. The anal opening absent, except for its internal structure, appear dorsally at the posterior end of the abdomen. The opening itself is not differentiated from the adjacent derm, many strong erected setae directed towards the opening. Vulvar opening surrounding with extreme short setae and multilocualr pores with bilocular or trilocualr centrer and (8-16) slightly reniform outer loculi with a thin inner rim; these pores form medial to submedial band anterior to vulvar opening (Fig. 11 A \& B). The presence of the vulva is an indication of full maturity of the adult female. Circatrix appear ventrally posterior to the genital opening (vulva), it is round to oval clear membranous area without pores or setae (Fig. 12).

The derm pores serve as producers of the secreted substance which so frequently protects the insect. They considerably variable in type, size and distribution. The derm near thoracis spiracle orifice with multilocualr pores measurning $5-7 H^{H}$ each with bilocular center and 6 - 9 outer loculi (Fig. 8). Same type of multilocular pores are arranged between hind coxae forming a transverse ovisac band 3 or 4 pores wide, each with bilocular or trilocular center and $6-8$ outerloculi (Fig. $13 \& 14)$. the pores of this band is responsible for the secretion of the ovisac, they secrete a thin waxy filaments which amalgamate together, thus forming the ovisac wall. Simple multilocular pores similar to pores of ovisac band, forming marginal clusters and covering derm on dorsal surface around other dorsal pores

Dorsal and ventral body setae are vary greatly in length (Fig.15). The dosal setae are comparatively long and flagellat, with a bulb - like base, while the ventral setae are short and thin (Figs. $12 \& 13$ ).

This study is in agreement with that which is carried out by Unruh \& Gullan (2008 b). Ezz et al., (1974) and 
Kosztarb (1996) described Icerya purchasi which is similar to great extent to I. aegyptiaca except the lacking of the quadrilocular disc pores with trilocular center. And the number of the circatrices which are three in I. purchasi, the central one is the largest while

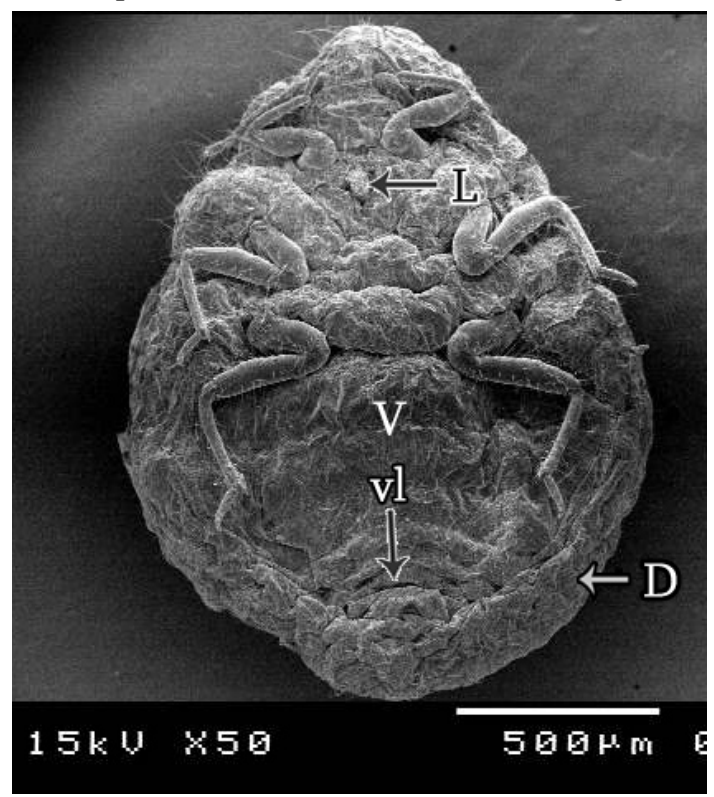

Figure 1. SEM micrograph of Icerya aegyptiaca female (D. dorsal side; $L$. labium; V. ventral side vl. Vulva).

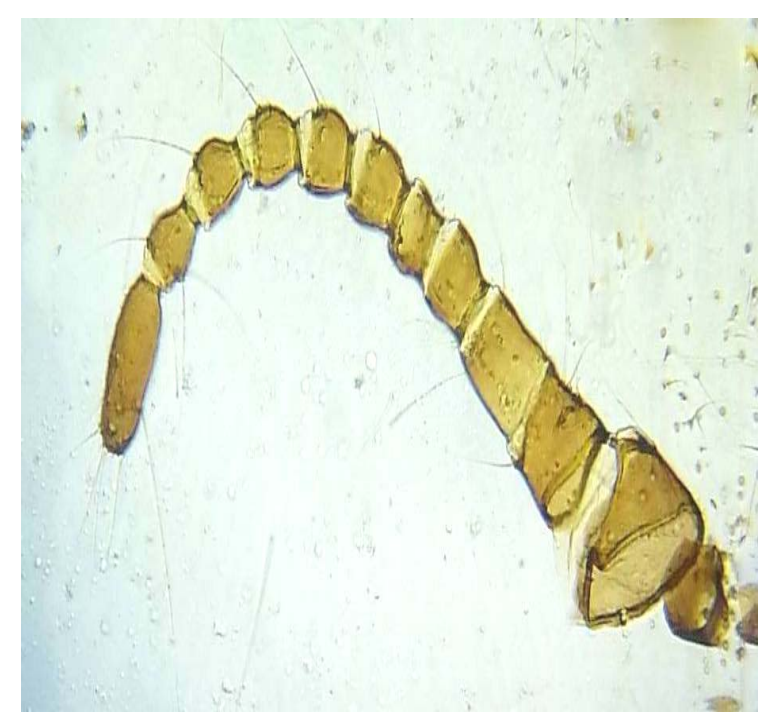

Figure 3. Light microscopic photograph showing the eleven segmented antenna and adjacent eye. in the present work, there is only one. Also, there were no distinguished body regions or tufts of hairs surrounding the body margin which are described by the previous authores.

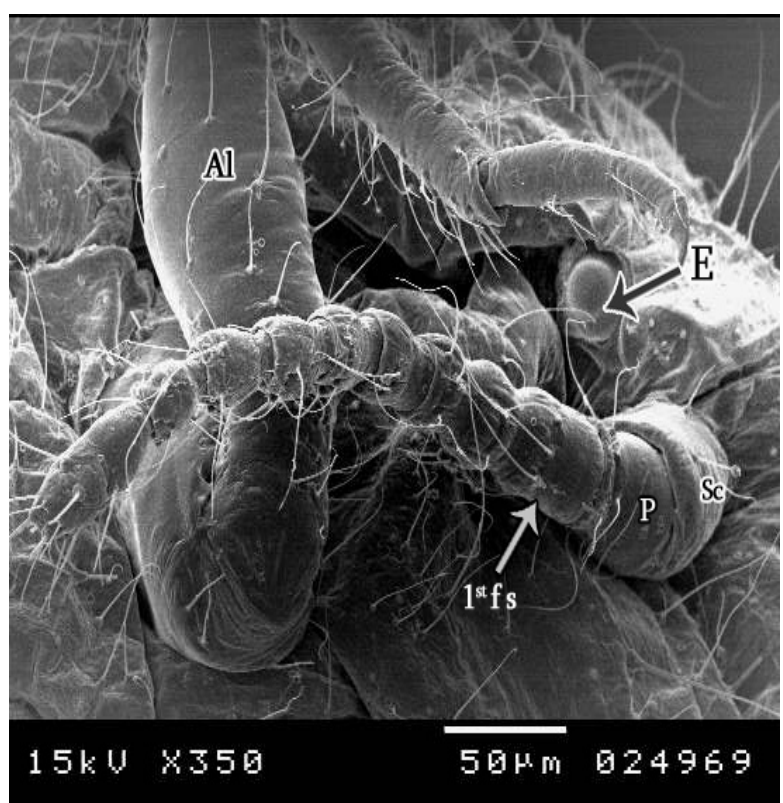

Figure 2. SEM micrograph showing antenna, eye and anterior leg (Al., anterior leg ; E. eye; P. pedicel; Sc. Scape and $1^{\text {st }}$ fs. flagellar segments )

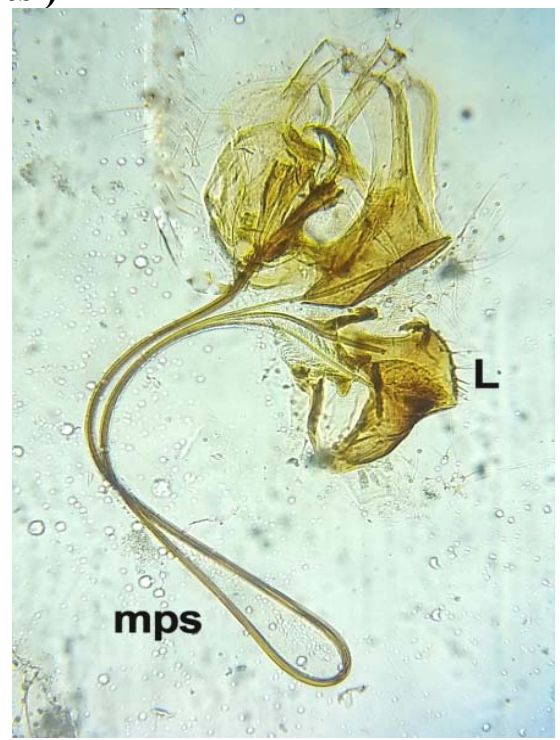

Figure 4. Light microscopic photograph showing the mouth parts(L. labium and mps. Mouth part stylets looped in crumena) 


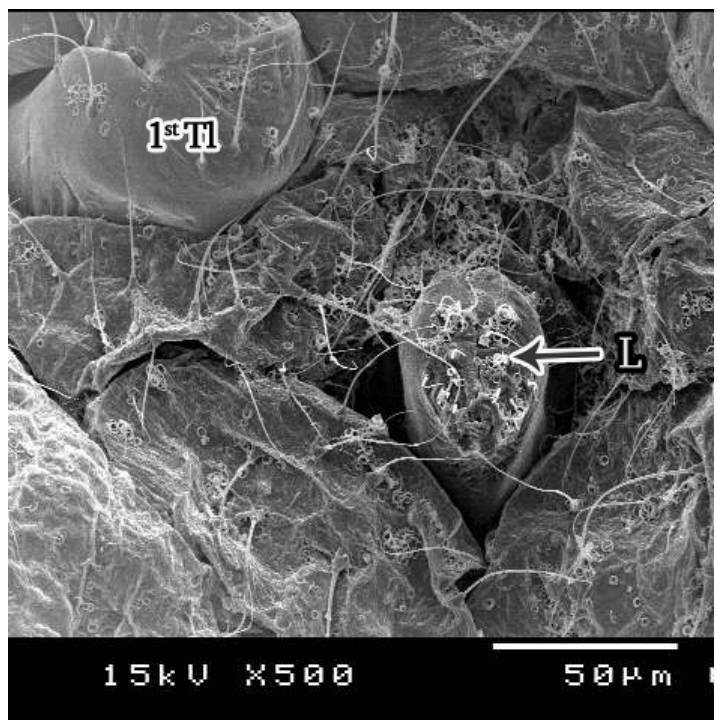

Figure 5. SEM micrograph showing labium (L.) and 1st thoracic leg (1st Tl.).

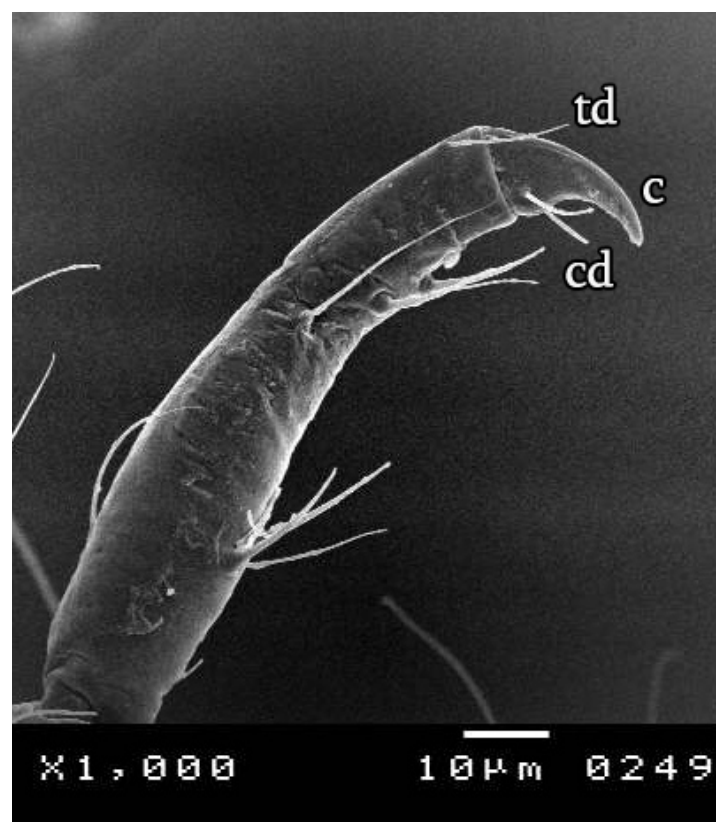

Figure 7. SEM micrograph showing one segmented tarsus and claw. (C. claw; cd. claw digitules and td. tarsal digitules)

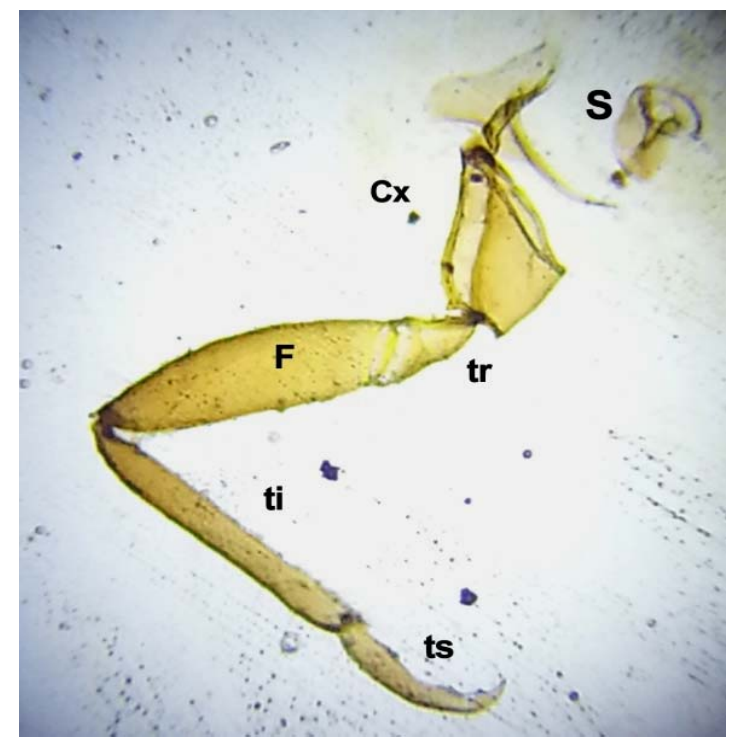

Figure 6. Light microscopic photograph showing leg and spiracle (cx. Coxa;F. femur; ti. Tibia; tr. Trochanter; ts. Ts. Tarsus. S. spiracle)

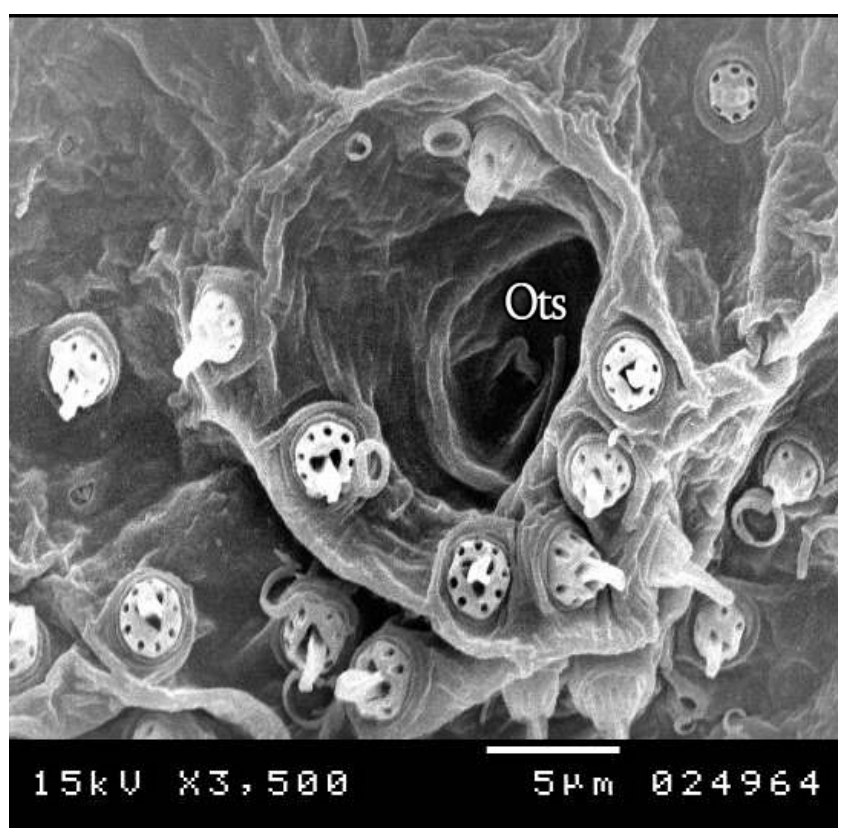

Figure 8. SEM micrograph showing orifice of thoracic Spiracles (Ots.) 


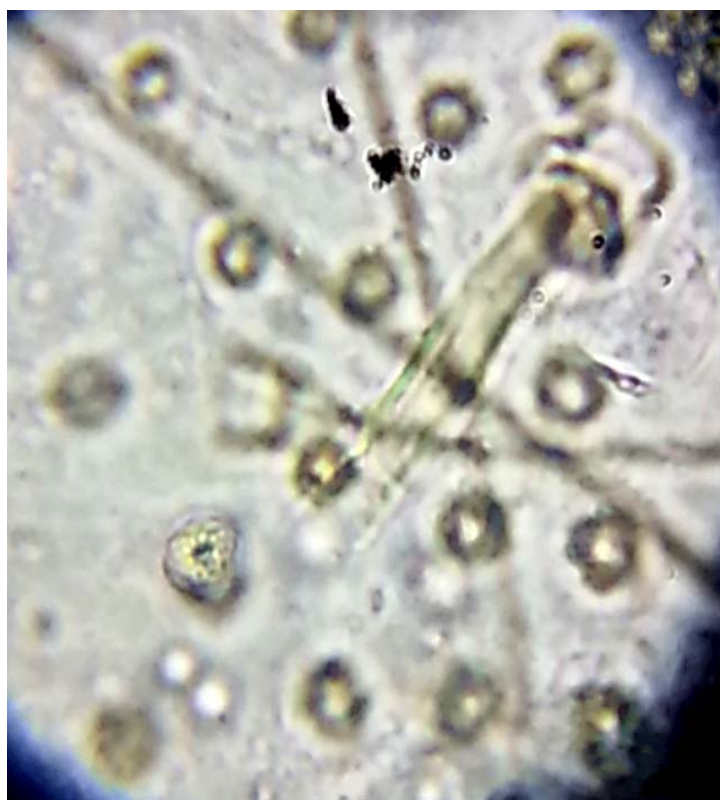

Figure 9. Light microscopic photograph showing abdominal spiracles

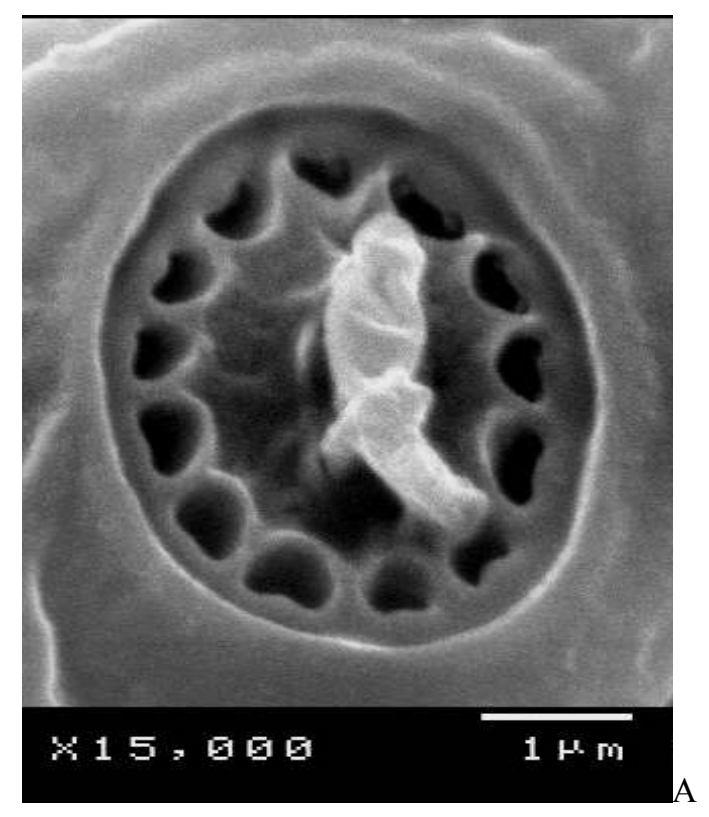

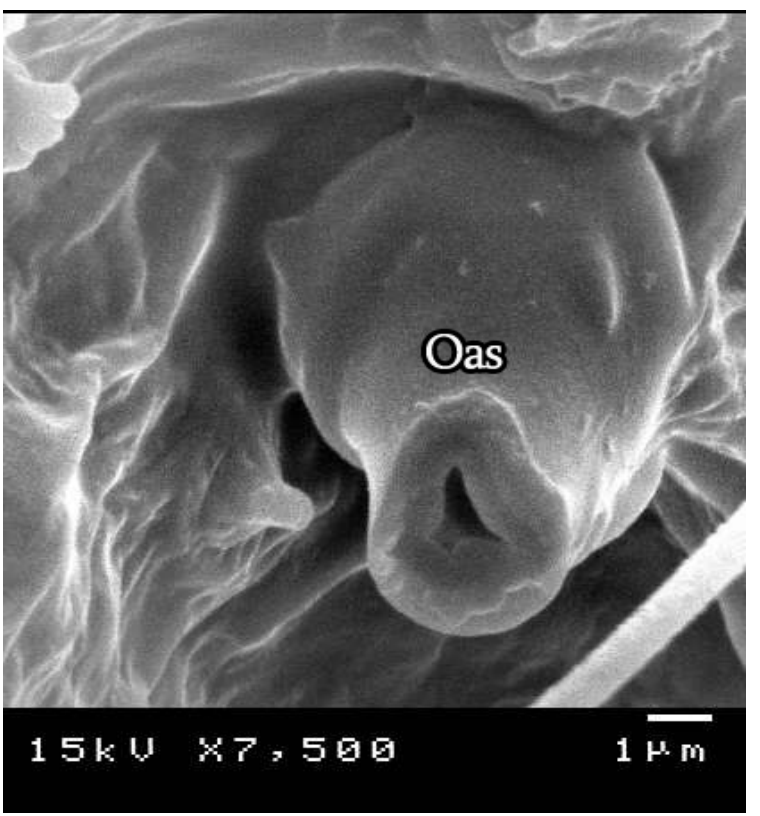

Figure 10. SEM micrograph showing bell shaped orifice of abdominal spiracles (Oas.)

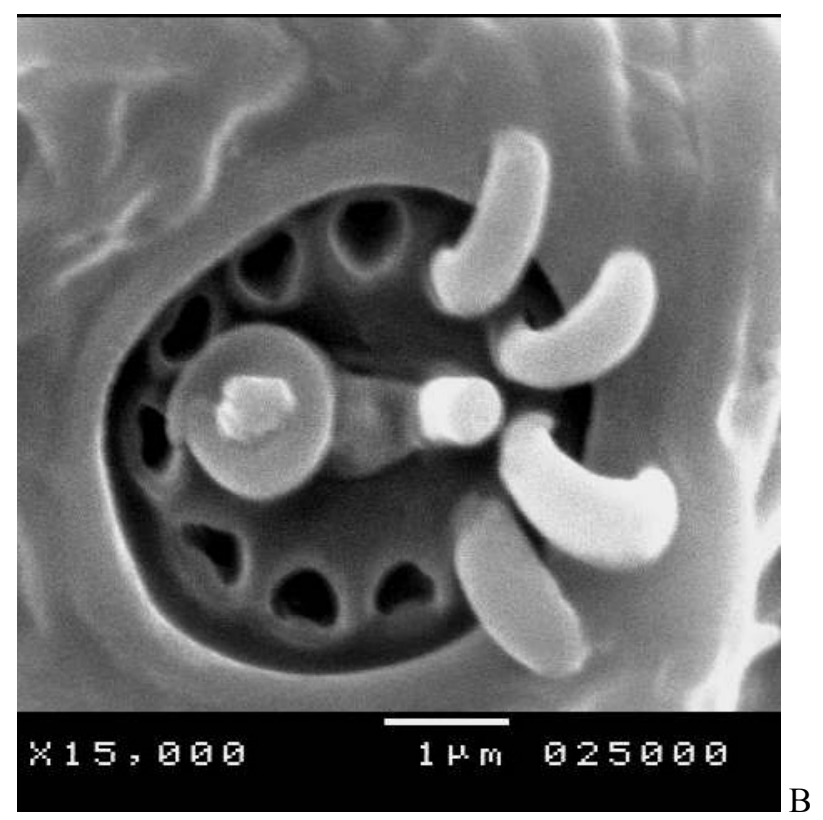

Figure 11 A\&B. SEM micrograph showing the multilocular pores with 11- 13 reniform loculi with bilocular center surrounding the vulva(wax filaments extruded from some loculi 


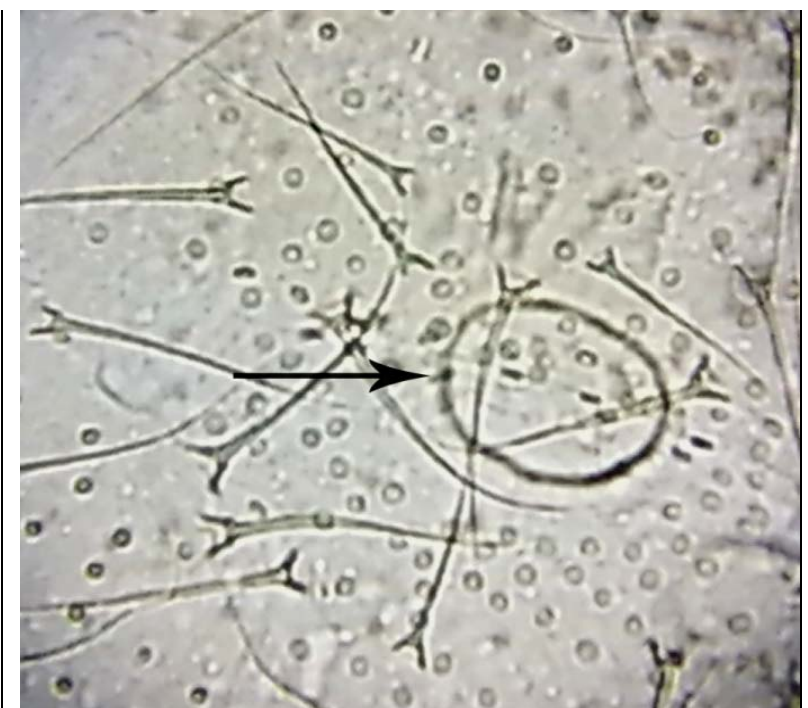

Figure 12. Light microscopic photograph, arrow indicating the rounded oval circatrix

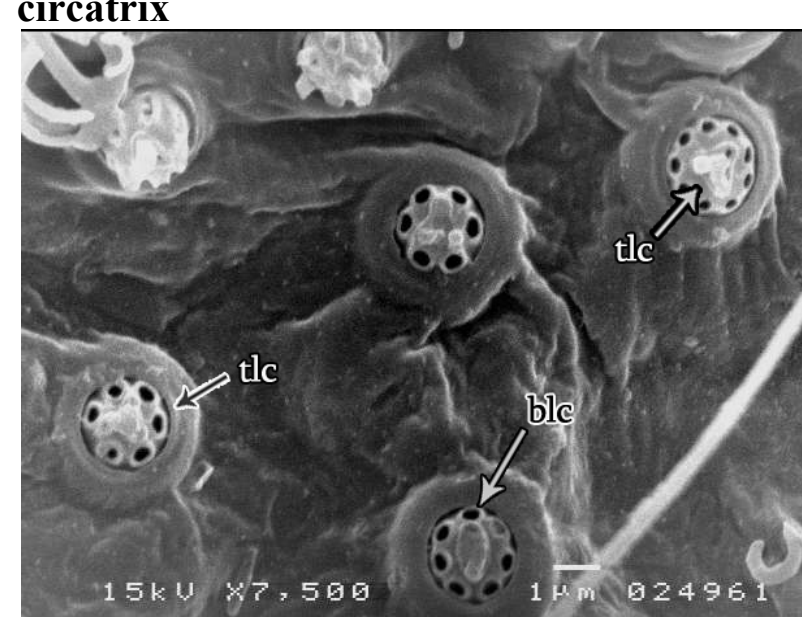

Figure 14. SEM micrograph showing the multilocular pores with 6 - 9 loculi with bilocular (blc) or trilocular (tlc) center of ovisac band

\section{ACKNOWLEDGMENTS}

The author is indebted with deep thanks to Professor Dr. Hedaya Hamza Karam, Department of applied Entomology, Faculty of Agriculture, Alexandria University, Egypt, for her assistance, careful review and her suggestions for improving the manuscript. Thanks also to Professor Dr. Hanan Mohamed Ramdan, in the same Department for her assistance in refining of SEM photos.

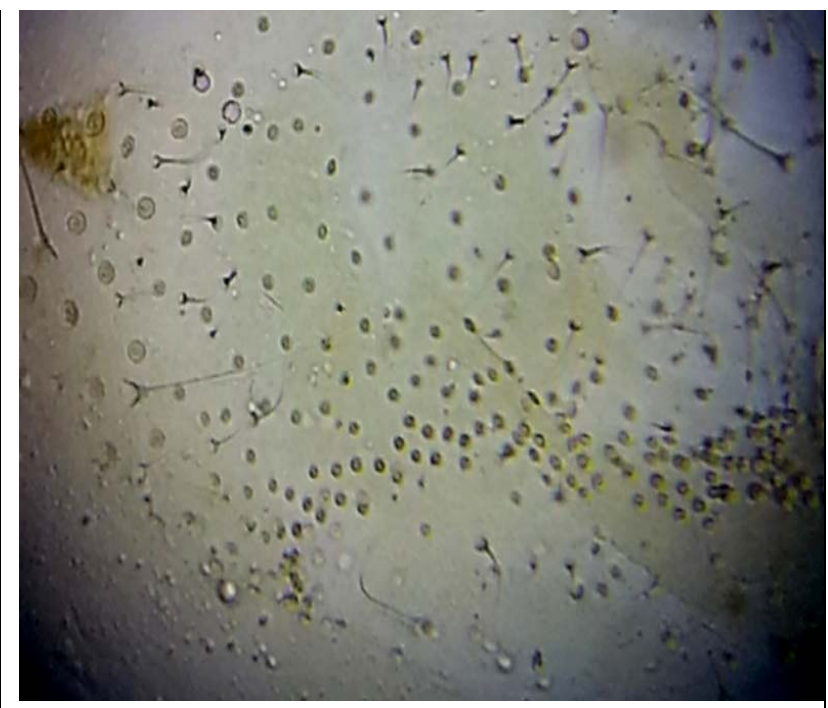

Figure 13. Light microscopic photograph, showing the transverse multilocular ovisac band

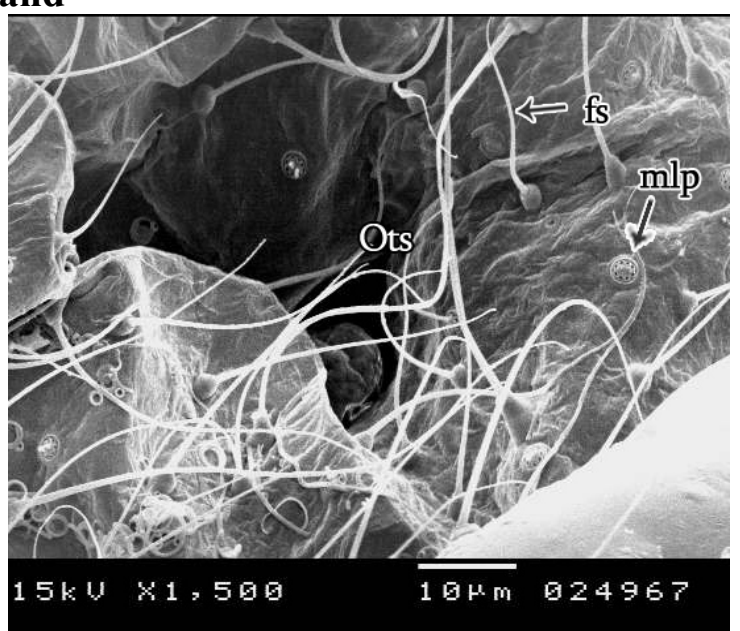

Figure 15. SEM micrograph showing variable length of dorsal Flagellate setae (fs. Flagellate seta; mlp. multilocular pores

\section{REFERENCES}

Ben-Dov,Y., D.R. Miller, and G.A.H. Gibson. 2006. Scale Net.

http://www.sel.barc.usda.gove/scalent/scalent.htm(Access ed5 August and 10 September 2007)

Borchsenias, N. 1956. The question of the course of evolution of coccoidea (Insecta, Homoptera). Zool . zhur. 35; 546 553. (In Russain)

Carnes, E.K. 1907. The Coccoidea of California Calif . State Comnt. Hort. Bien. Rept.2(1905 106): 155 - 222. 
Ezz, A.I., A.H. EL-KIIL , A.G. Saad, and A. Wahab.1974. Morphological and Ecological studies on Icerya purchsi Mask. In Egypt. ${ }^{\text {nd }}$ Egt. Pest . cont. cong. Alexandria. Vol. 11, Alex - Univ. 10-12 sept. $1974: 617$ - 657

Ezzat, Y. M., and S.M. A. Nada. 1986. List superfamily Coccoidea as know to exist in Egypt. Bull. Lab. Entomol Agr. "Fillippo silvestri" : $43: 85-90$.

Gullan, P.J., and L.G. Cook. 2007. Phylogeny and higher classification of the scale insects (Hemiptera : Sternorrhyncha: coccoidea) www.mapress.com/Zootaxa $1668: 313-425$

Kosztarab, M.1996. Scale Insects of Northeastern North America: Identification, Biology, and distribution.Virqinia Museum of Natural History, Martineville. Special publication No.3, $650 \mathrm{pp}$.

Koteja, J. 1974. On the phylogeny and classification of the scale insects (Homoptera, Coccinae) (discussion based on the morphology of the mouth parts). Acta zoological Cracoviensia. 19: 267 - 326.

Koteja, J.1996. Scale insects (Homoptera: Coccinae) a day after. In: Schaefer, C.W. (Ed.), Studies on Hemipteran phylogeny. Proceedings of Thomas Say Publications in Entomology, Entomological society of America, Lanham, Maryland, pp. $65-88$.

Koteja, J.2001. Essays on coccids (Hemiptera: Coccinae): paleontology without fossils. Prace Museum ziemi, 46, 41 -53 .

Miller, D.R., and J.A. Davidson. 1990. A list of the armored scale insects pests. In: Rosen, D. (Ed), World Crop pests, Volume 4 B, Aromored Scale Insects: their Bilology, Natural Enemies and control. Elsevier, Amsterdam, pp. 299- 306.
Miller, D.R., M.E. Gimpel, and A. Rung. 2005. A systematic Catalogue of the Cerococcidae, Halimococcidae, Kermesidae, Micrococcidae, Ortheziidae, Phenacoleachiidae, Phoenicoccidae and Stictococcidae (Hemiptera: coccoidea) of the world. Intercept Limited, wimborne.

Miller, D.R., A. Rung, G.L. Venable, and R.J. Gill. 2007. Scale Insects: identification tools for species of quarantine importance scale families. ARS \& APHIS, USAD. Avail able from :http://www.sel.barc.usda.gov/Scale keys/scale insectsHome/ scaleInsects Families. Htmi (accessed5Septmeber2007)

Morrison, H. 1928. A classification of the higher groups and genera of the coccid. Family Margarodidae. U.S. Dept. Agric. Tech. Bull. 52: 1 - 240, 7.

Snodgrass, R.E. 1935. Principles of insect morphology, McGRAW-Hill Book Comany, Inc. New York and London pp.667.

Williams, D.J., and G.W. Watson. 1990 . The scale Insects of the Tropical South Pacific Region. Pt. 3; The soft scales (Coccidae) and other families. $\mathrm{CAB}$ International Institute of Entomology, London, $272 \mathrm{pp}$.

Unruh, C.M., and P.J. Gullan. 2008 a. Molecular data reveal convergent reproductive strategies in iceryine scale insects (Hemiptera: coccoidea: Monophlebidae), allowing re-interpretation of morphology and revised generic classification. Systematic Entomology. 33: 8- 50.

Unruh, C.M., and P.J. Gullan. 2008 b. Identification guide 2 species in the scale insect tribe Iceryini (coccoidea: Monophlebidae) Zootaxa 1803, Mangolia press; 1 - 106 


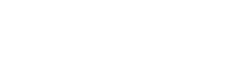

\section{درلسة بالميكروسكوب الإلكتروف الملسح للق القيقي المصري \\ Icerya aegyptiaca (Douglas 1890)}

سحرر محمد بشرر

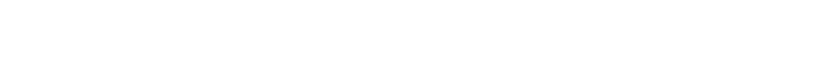

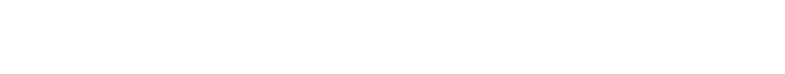
من الثغور التفسية الطنية وهي الصغر حجماً من الصدرية.

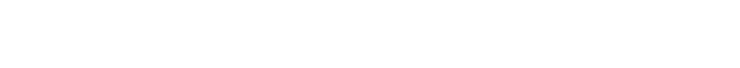
توجد الفتحة التنلسلية علي النالحية الطنية. ويحتوى ج سم الطم الطية

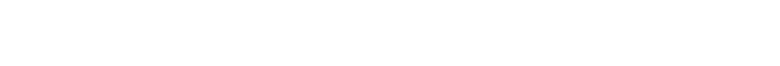

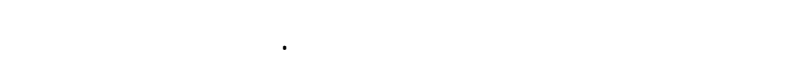

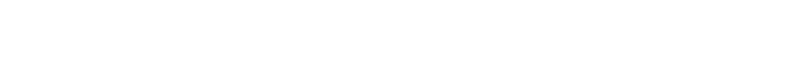

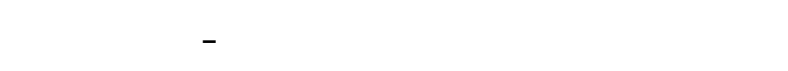

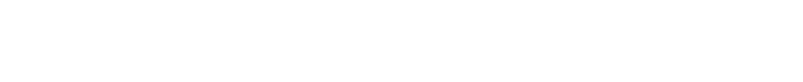

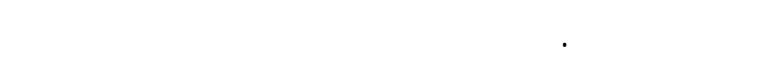

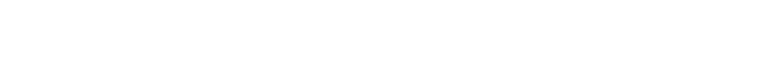

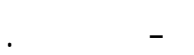

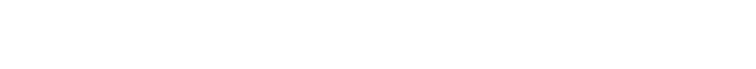

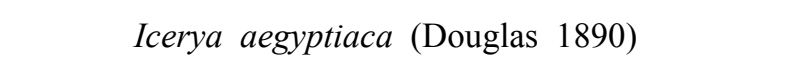
الصفلت الخارجية لها بولنطة الميكروسكوب الالكترون ي لميكي

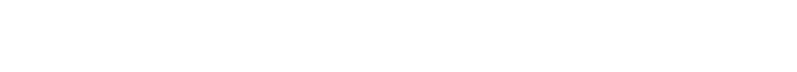
الدقيقي يعتمد أسلسا علي الإنلث.

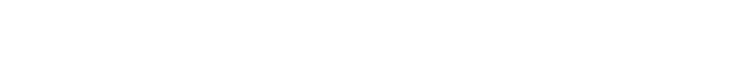

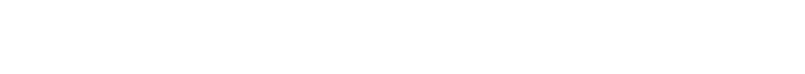

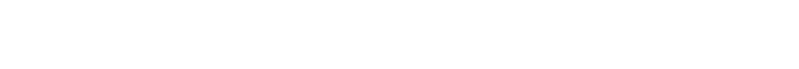

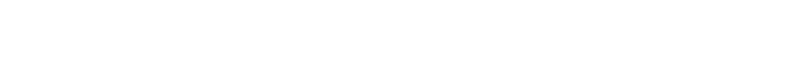

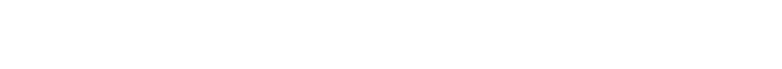
ولا يوجد عليها حلقلت بطنيه. يوجد عله مطقة الرئس زوج من ق ـرون الإست شعار مقنم إلى 11 كقلة ولها زوج من الأعن الدائرية الـ ششكل 